\title{
Bone Morphogenetic Protein-7 and Connective Tissue Growth Factor: Novel Targets for Treatment of Renal Fibrosis?
}

\author{
Tri Q. Nguyen ${ }^{1}$ and Roel Goldschmeding ${ }^{1,2,3}$
}

\author{
Received December 30, 2007; accepted January 28, 2008; published online Ferbruary 12, 2008
}

\begin{abstract}
Renal fibrosis is the major determinant in progression of kidney disease and results from an inappropriate response to acute and chronic kidney injury. Transforming growth factor (TGF)- $\beta 1$ is the driving force behind renal fibrosis and has since long been regarded as the key factor to be targeted in prevention and treatment of renal fibrosis. Despite the impressive results obtained in experimental renal fibrosis, TGF- $\beta 1$ blockade has not yet translated into an effective and safe therapeutic in human patients. Therefore, it remains important to explore the role of additional growth factors which are involved in renal regeneration and fibrosis. Recently, bone morphogenetic protein (BMP)-7 and connective tissue growth factor (CTGF) have both emerged as novel modulators of profibrotic TGF- $\beta 1$ activity. The expression of BMP-7 is decreased in various models of renal disease, while CTGF is strongly upregulated in experimental and human renal fibrosis. In experimental kidney injury, administration of BMP-7 or inhibition of CTGF have been sufficient to result in striking improvement of renal function and structure. This review summarizes the current knowledge of BMP-7 and CTGF in the kidney, and discusses their therapeutic potential in renal fibrosis.
\end{abstract}

KEY WORDS: bone morphogenetic protein-7; connective tissue growth factor; diabetic nephropathy; renal fibrosis; transforming growth factor- $\beta$.

\section{BACKGROUND}

\section{Renal Fibrosis}

Renal fibrosis is the major determinant in progression of kidney disease and results from a general set of responses to acute and chronic kidney injury, irrespective of the initial cause. Renal fibrosis is characterized by excessive accumulation of extracellular matrix (ECM) components leading to glomerulosclerosis, tubulointerstitial fibrosis, inflammatory infiltration, loss of renal parenchyma, and renal vascular changes. The origin of matrix production in the kidney is not completely understood, but might include activation of resident fibroblasts, epithelial and mesangial cells, migration of haematopoietic or mesenchymal stem cells from the bone marrow, migration of periadventitial cells, and epithelialto-mesenchymal transition (EMT) of tubular epithelial cells $(1,2)$.

\section{Fibrosis, Response to Injury, and Growth Factors}

Under physiological conditions, local damage or altered environmental factors will result in an appropriate response to

\footnotetext{
${ }^{1}$ Department of Pathology, University Medical Center Utrecht, Utrecht, The Netherlands.

${ }^{2}$ Department of Pathology-H04.312, University Medical Center Utrecht, Heidelberglaan 100, 3584 CX, Utrecht, The Netherlands.

${ }^{3}$ To whom correspondence should be addressed. (e-mail: R.Gold schmeding@umcutrecht.nl)
}

injury of the affected kidney resulting in minimal scarring and optimal repair and functional recovery. However, in many instances, inappropriate response to injury occurs, favoring scar formation over repair. This contributes significantly to progressive renal fibrosis, and subsequently to end-stage renal failure. The precise molecular mechanisms of renal fibrosis have not been fully elucidated, but renal response to injury is considered to be determined by the expression level of certain growth factors. Transforming growth factor (TGF)- $\beta 1$ is generally regarded as the key mediator in the development of renal fibrosis (3). Although many therapeutic approaches have been explored to inhibit TGF- $\beta 1$ activity in experimental models of renal disease, thus far no antiTGF- $\beta 1$ therapy has been applied in a clinical setting (4). Therefore, it remains important to explore the role of additional growth factors which are involved in renal regeneration and fibrosis. In this respect, bone morphogenetic protein (BMP)-7 and connective tissue growth factor (CTGF) might be attractive novel targets in the treatment of renal fibrosis.

\section{TGF-B1 IS THE DRIVING FORCE BEHIND RENAL FIBROSIS}

\section{Transforming Growth Factor- $\beta 1$ (TGF- $\beta 1)$}

TGF- $\beta 1$ is a member of the TGF- $\beta$ superfamily, which consists of more than 30 growth factors, including BMPs, inhibins, and activins (5). Members of the TGF- $\beta$ superfamily 
signal through binding to type I and type II serine/threonine kinase receptors. Upon ligand binding and receptor complex activation, receptor regulated (R)-Smads are phosphorylated. Phophorylated R-Smads bind to their common partner Smad4, and subsequently translocate into the nucleus where they act as transcription factors. The specificity of the signal is mainly determined by the type I receptor, also known as activin receptor-like kinase (ALK), and the R-Smads. In general, TGF- $\beta$ s bind ALK5 and activate Smad 2 and -3 , while BMPs bind ALK2, -3 , and -6 , and activate Smad1, -5 , and -8 (6).

In mammals, three isoforms of TGF- $\beta$ (TGF- $\beta 1$, TGF$\beta 2$, and TGF- $\beta 3$ ) have been identified, which are encoded by genes lying on separate chromosomes, but share a high degree of homology. Since all TGF- $\beta$ isoforms also show comparable in vitro biological activities and signal through the same set of receptors, it has been suggested that they have equal biological activity in vivo. However, studies with TGF- $\beta$ isoform-specific knockout mice have revealed that each TGF$\beta$ isoform exerted specific and non-compensated functions, which might relate to their individual expression regulation and distribution (7). The effects of TGF- $\beta 1$ are multifunctional and, in addition to its fibrogenic role as main inducer of ECM production, the functions of TGF- $\beta 1$ also include regulation of cell growth, cell differentiation, cytokine production, and immune cell modulation (8-10).

\section{TGF- $\beta 1$ Expression in Renal Fibrosis}

The relevance of TGF- $\beta 1$ in renal disease was first reported in a landmark study by Border et al., who provided direct evidence for a causal role of TGF- $\beta 1$ in ECM accumulation in experimental acute mesangial proliferative glomerulonephritis (11). Subsequently, upregulation of TGF$\beta 1$ expression has been demonstrated in a wide variety of other experimental diseases associated with renal fibrosis, including anti-glomerular basement membrane disease, obstructive nephropathy, hypertensive nephrosclerosis, and diabetic nephropathy (12-15). In human renal biopsies, upregulation of TGF- $\beta 1$ and isoforms was observed in glomerular and tubulointerstitial diseases characterized by ECM accumulation, but not in renal disorders where ECM accumulation was not a feature (15-17). In addition, levels of circulating and/or urinary TGF- $\beta 1$ protein were shown to be elevated in patients with renal fibrotic diseases like chronic allograft nephropathy, focal segmental glomerulosclerosis, and diabetic nephropathy (18-20).

\section{Inhibition of TGF- $\beta 1$ Activity}

Several therapeutic strategies have been applied successfully to inhibit profibrotic TGF- $\beta 1$ activity in experimental models of renal fibrosis. These approaches include inhibition of TGF- $\beta 1$ by neutralizing antibodies, antisense oligodeoxynucleotides, soluble TGF- $\beta 1$ receptors, and blockade of TGF$\beta 1$ activation by decorin (11,21-24). Recently, the use of a small molecule inhibitor of the specific TGF- $\beta$ receptor ALK5 proved to be effective in suppression of renal fibrosis in rat models of puromycin-induced nephritis and obstructive nephropathy $(25,26)$. In addition, a novel small molecule inhibitor selective for ALK5 and the TGF- $\beta$ type II receptor was capable of reducing renal fibrosis in diabetic $\mathrm{db} / \mathrm{db}$ mice (27).

Despite the impressive results obtained in experimental renal fibrosis, TGF- $\beta 1$ blockade has not yet translated into an effective and safe therapeutic in human patients. This might relate to concern about possible adverse effects of TGF- $\beta 1$ inhibition. The observation that TGF- $\beta 1$ knockout mice display an autoimmune and hyperinflammatory phenotype, while transgenic mice overexpressing TGF- $\beta 1$ are protected from renal inflammation, underscores the important role of TGF- $\beta 1$ in controlling accurate levels of inflammatory activity $(28,29)$. Furthermore, studies in which inhibition of TGF- $\beta 1$ activity resulted in enhanced tumorigenesis, both in TGF- $\beta 1^{+/-}$mice and in nude mice injected with a dominantnegative mutant TGF- $\beta$ type II receptor, confirms that TGF$\beta 1$ also has relevant functions in anti-proliferation and tumor suppression $(30,31)$. Thus, considering the multifunctional biological activities of TGF- $\beta 1$, it is important to explore therapeutic strategies that are aimed at targeting the downstream effectors or the signaling pathway of TGF- $\beta 1$ that specifically mediates its fibrogenic action. In this respect, BMP-7 and CTGF have both appeared as promising targets for modulation of profibrotic TGF- $\beta 1$ activity.

\section{BMP-7 IS DOWNREGULATED IN RENAL FIBROSIS}

\section{Bone Morphogenetic Protein-7 (BMP-7; OP-1)}

The TGF- $\beta$ superfamily comprises over twenty BMPs, of which BMP-7 (also called osteogenic protein-1 or OP-1) is the most prominent member involved in renal development and disease. BMPs are differentially expressed throughout development, and it was demonstrated that in particular BMP-7 and BMP-4 are important in the developing kidney. Initially, BMP-7 is expressed in the ureteric bud. Later in development, BMP-7 is also found in the metanephric mesenchyme, early tubules, and eventually in the podocytes of mature glomeruli (32-35). The relevance of BMP-7 in renal development was observed in homozygous BMP-7 knockout mice, which showed reduction in branching of the ureteric bud and loss of metanephric mesenchyme, resulting in severe renal hypoplasia (32). In the adult kidney, BMP-7 is expressed in glomerular podocytes, the thick ascending limb, the distal convoluted tubule, and most strongly in the collecting duct (36).

\section{BMP-7 Expression in Renal Fibrosis}

In contrast to the consistent upregulation of TGF- $\beta 1$ in models of experimental and human renal fibrosis, expression of BMP-7 was shown to be markedly reduced in experimental diseases associated with renal fibrosis. For example, the expression of BMP-7 mRNA and protein was downregulated after ischemia-reperfusion injury, unilateral ureteral obstruction (UUO), pyelonephritis, chronic allograft nephropathy, and in genetic murine models of Alport syndrome and lupus nephritis (37-43). In streptozotocin-induced diabetic rats, renal expression of BMP-7 was decreased by more than $90 \%$, and this was accompanied by downregulation of the BMP type II receptor and the type I receptor ALK2 (44). Decrease of BMP-7 expression was also evidenced in mouse 
podocytes cultured under high glucose, and in renal biopsies of patients with diabetic nephropathy $(45,46)$. Thus far, the latter study is the only report available demonstrating decrease of BMP-7 expression in human patients. In addition, loss of BMP-7 signaling activity, as illustrated by lower phosphorylated Smad1/5 protein levels, was observed in experimental nephrotoxic serum nephritis and diabetic nephropathy $(47,48)$.

\section{EFFICACY OF BMP-7 AS AN ANTIFIBROTIC DRUG}

\section{In Vitro Antifibrotic Effects of BMP-7 in Renal Cells}

The function of BMP-7 in the adult kidney has not been revealed completely, but recent evidence suggest that endogenous BMP-7 might function as a regulator of kidney homeostasis and regeneration by maintaining a differentiated epithelial phenotype of tubular epithelial cells $(48,49)$. In vitro studies have demonstrated that BMP-7 is a potent antagonist of TGF- $\beta 1$ mediated effects on renal cells. In particular, BMP-7 proved to be a potent inhibitor of TGF- $\beta 1$ induced EMT of proximal tubular epithelial cells (47). Other protective effects of BMP-7 in proximal tubular epithelial cells include inhibition of TGF- $\beta 1$ production, decrease of proinflammatory genes and chemoattractants, and inhibition of EMT induced by multiple myeloma light chains $(36,50,51)$. Also in mesangial cells and podocytes, BMP-7 was able to inhibit adverse effects caused by TGF $\beta 1$, aldosterone, or high glucose $(45,46,52,53)$. The remarkable potential of BMP-7 even to reverse fibrosis was demonstrated by its ability to induce formation of epithelial cell aggregates in cultures of adult renal fibroblasts, which was accompanied by acquisition of E-cadherin expression and decreased motility, indicating that true mesenchymal-to-epithelial transition (MET) might also be achieved (54).

\section{BMP-7 Therapy in Experimental Fibrosis}

In vivo evidence for antifibrotic properties of BMP-7 was first demonstrated by Vukicevic et al. (55), who showed that BMP-7 reduced severity of renal injury after ischemiareperfusion by temporary bilateral renal artery occlusion in rats. In this study, intravenously administered BMP-7 preserved kidney function as evidenced by reduced blood urea nitrogen and serum creatinine, and it also attenuated proteinuria while increasing survival rate. In subsequent studies, others showed that BMP-7 prevented renal fibrogenesis associated with ureteral obstruction, and effectively restored renal function if administered during the progression of this fibrotic disease $(39,56)$.

The in vitro potential of BMP-7 to inhibit EMT and to induce MET was confirmed in a mouse model of chronic injury caused by nephrotoxic serum nephritis, in which reversal of renal fibrosis was observed even with BMP-7 therapy starting several weeks after the occurrence of damage $(47,54)$. The same investigators also showed that BMP-7 therapy could attenuate progression of renal disease in genetic mouse models of lupus nephritis and Alport syndrome (43). However, the therapeutic potential of BMP-7 has been investigated most extensively in experimental diabetic nephropathy, which in human patients is the leading cause of end-stage renal disease. In streptozotocin-induced diabetic rats, both glomerular and tubulointerstitial damage as well as albuminuria were significantly attenuated by BMP-7 therapy in a dose-dependent manner (57). A similar effect on structural changes was observed after BMP-7 treatment in diabetic CD1 mice. In that study, BMP-7 had no effect on albuminuria (58). However, in diabetic transgenic mice overexpressing BMP-7 in podocytes and proximal tubuli, the severity of glomerulosclerosis, interstitial fibrosis, and albuminuria were all markedly decreased (48).

The therapeutic potential of BMP-7 reaches beyond its efficacy in the kidney. In the liver, BMP-7 treatment attenuated $\mathrm{CCl}_{4}$-induced fibrosis by inhibition of hepatocyte-to-fibroblast transition, and it facilitated hepatocyte regeneration, and accelerated restoration of liver function in mice after partial hepatectomy $(59,60)$. However, the antifibrotic effect of BMP-7 in the liver remains controversial, since one study has recently demonstrated that BMP-7 expression was upregulated in the cirrhotic human liver, and that BMP-7 could induce production of collagen and fibronectin in hepatic stellate cells (61). In rats with inflammatory bowel disease, systemic administration of BMP-7 led to less severe colitis with preserved histology and suppression of proinflammatory and profibrogenic genes (62). Administration of BMP-7 also inhibited the progression of cardiac fibrosis in mouse models of pressure overload and chronic allograft rejection, probably by counteracting TGF- $\beta 1$ induced endothelial-to-mesenchymal transition (63). In line with its strong osteogenic properties, intraperitoneal injection of BMP-7 was successful in treatment of renal osteodystrophy and adynamic bone disorder in mice $(64,65)$. Paradoxically, however, BMP-7 inhibited vascular calcification in a murine model of renal failure associated atherosclerosis, rendering it almost a panacea (66).

Local BMP-7 therapy is currently under study in human orthopedic patients to improve healing of fractures and nonunions, and for spinal fusion (67). Thus far, clinical trials with BMP-7 have not been performed in renal diseases, and it remains to be established whether ectopic bone formation or other adverse effects might occur after systemic administration of BMP-7.

\section{Possible Role for Other BMPs}

Most of the antifibrotic potential of BMP-7 has been attributed to its ability to antagonize the injurious effects driven by TGF- $\beta 1$. However, little is known about the mechanism by which the interaction between these two growth factors occurs. Interestingly, the protective effect of BMP-7 on preservation of TGF 31 -induced downregulation of E-cadherin expression in tubular epithelial cells could be mimicked by transfection with the constitutively active general BMP type I receptor ALK3 (47). Furthermore, expression of thrombospondin-1 (TSP-1), which is the major activator of latent TGF- $\beta 1$ in experimental glomerulonephritis and diabetic nephropathy, was repressed by the prototypical BMP target gene Id1 $(68,69)$. These data suggest that these antifibrotic effects are not entirely specific for BMP-7, and that other BMPs might have similar anti-TGF $\beta 1$ activity. In this respect, it is noteworthy that both BMP-4 and BMP-6 were able to functionally substitute for loss of BMP-7 during 
kidney development (70), and that BMP-6 could inhibit TGF 31 -induced expression of CTGF and plasminogen activator inhibitor-1 in renal interstitial fibroblasts (71). Our observations that myofibroblast progenitor cells derived from patients with diabetes were deficient in BMP-6 expression (71), and that in renal cortex of diabetic mice, BMP-4, -5 , and -6 were decreased to a similar extent as BMP-7 (Fig. 1), indicate that, in addition to BMP-7, also other BMPs might play an important role as antagonists of renal fibrosis.

Despite apparent overlap in functions of other BMPs with BMP-7, it should be kept in mind that distinct biological effects have been attributed to different BMPs. For instance, BMP-6 and BMP-7 exhibited differential and specific effects on survival and outgrowth of neurons, and opposite effects of BMP-2 and BMP-7 have been reported on renal branching morphogenesis (72,73). Moreover, the inhibitory effect of BMP-7 on vascular calcification was not observed with BMP2 and BMP-4, which were both shown to promote calcification of vascular smooth muscle cells $(74,75)$.

\section{Modulators of BMP-7}

The activity of BMP-7 in the kidney can be enhanced or inhibited by extracellular modulators. Recently, kielin/chordin-like protein (KCP) was identified as a novel enhancer of BMP signaling. $\mathrm{KCP}^{-1-}$ mice, which have less pSmad1 protein, developed significantly more renal damage and interstitial fibrosis after induction of UUO or acute tubular necrosis (76). In addition, pSmad2 protein levels were increased in $\mathrm{KCP}^{-/-}$mice, suggesting that the antifibrotic effect of KCP also included inhibition of TGF- $\beta 1$ activity (77). Also, several extracellular modulators have been identified that inhibit BMP-7 activity, including uterine sensitization-associated gene (USAG)-1, which is abundantly expressed in the kidney. USAG- $1^{-1-}$ mice had increased pSmad1/5 protein levels and exhibited prolonged survival and preserved renal function after cisplatin nephrotoxicity or UUO. The renoprotection in these mice could be abolished
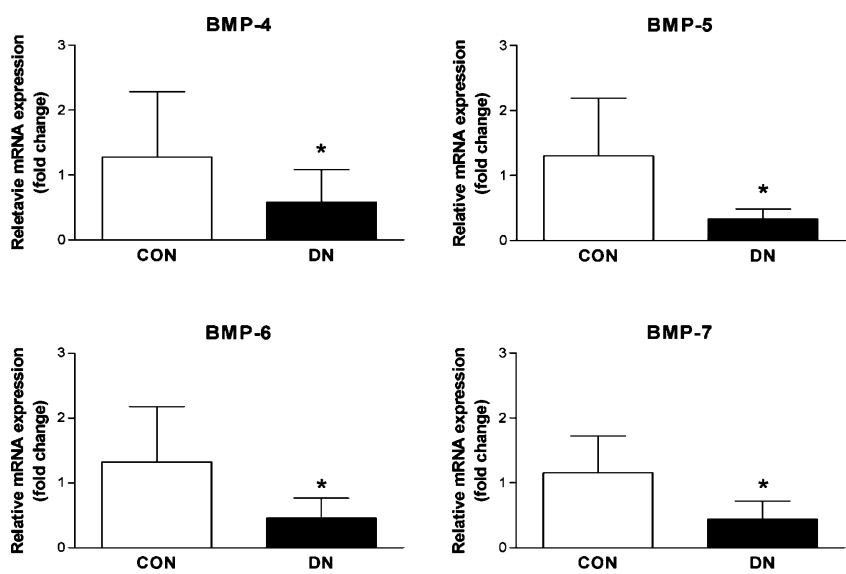

Fig. 1. BMP-4, $-5,-6$, and -7 are similarly decreased in renal cortex of diabetic mice. Diabetic nephropathy (DN) was induced in 12-week old female C57Bl6/J mice by intraperitoneal injection with streptozotocin $(N=16)$. Renal cortex was harvested 9 weeks after induction. Expression of BMP genes was assessed by quantitative PCR. Results are expressed as mean $\pm \mathrm{SD}\left({ }^{*} P<0.05\right)$. by administration of a neutralizing antibody against BMP-7 (78). Moreover, in mice with folic acid nephrotoxicity, the renal expression of USAG-1 at day 7 correlated with serum creatinine at day 14 , suggesting that USAG-1 expression in a kidney biopsy could be useful in predicting outcome (79). Recently, SclerOSTin domain-containing-1 or SOSTDC1 was identified as the human ortholog of USAG-1 and was shown to be highly expressed in normal kidney, but downregulated in renal clear cell carcinoma (80). Other antagonists of BMP-7 in the kidney include gremlin and noggin, of which overexpression of the latter in podocytes has been shown to result in massive mesangial matrix expansion $(81,82)$.

Taken together, these data indicate that the antifibrotic BMP activity in the kidney is not determined by the expression levels of BMP-7 alone, but that expression of multiple other BMPs and BMP modulators might be equally important. Moreover, the previously cited efficacy of inhibiting TGF- $\beta 1$ without BMP suppletion indicates that, more in general, modulation of the balance between BMP- and TGFB1-signaling activity might be the key to restoration of appropriate response to injury and reversal of fibrosis. In this respect, a modulator of particular interest is CTGF, which is able to both enhance TGF $\beta 1$ activity, and inhibit BMP-4 activity (83).

\section{CTGF IS AN EXTRACELLULAR MODULATOR OF MULTIPLE SIGNALING ACTIVITIES}

\section{Connective Tissue Growth Factor (CTGF; CCN-2)}

CTGF was first identified in conditioned media of endothelial cells as a $36-38 \mathrm{kDa}$ cysteine-rich polypeptide containing chemotactic and mitogenic activity towards fibroblasts (84). Subsequently, CTGF was acknowledged as a member of the CCN (CTGF/Cyr61/Nov) family, and became also known as CCN-2 (85). The CCN family consists of six matricellular regulatory proteins, consistent with the notion that they act by binding to extracellular signaling molecules via their multiple distinct interaction domains, rather than by signaling through direct binding to unique receptors specific to individual CCNs (86).

Domain 1 of CTGF consists of an N-terminal insulin-like growth factor binding protein, which is involved in binding of CTGF to insulin-like growth factor (IGF)-1 and fibronectin $(87,88)$. Domain 2 of CTGF shares high homology with Von Willebrand Factor type $\mathrm{C}$ repeats as well as with chordin, and is responsible for binding of CTGF to TGF- $\beta 1$ and BMP-4 (83). Domain 3 of CTGF contains a TSP-1 repeat and is involved in binding to vascular endothelial growth factor (VEGF), as well as binding to low-density lipoprotein receptor-related protein (LRP)-1 and integrin $\alpha 6 \beta 1$ (89-91). Domain 4 of CTGF is a C-terminal cysteine-rich domain. This domain is involved in binding of CTGF to heparan sulfate proteoglycans (HSPG), integrin $\alpha \mathrm{v} \beta 3$, fibronectin, and to the Wnt co-receptor LRP-6 $(88,92-94)$. Domain 4 is presumed to also interact with the neurotrophin receptor TrkA, which leads to induction of the transcription factor TGF- $\beta$-inducible early gene (TIEG) (95). In addition, CTGF contains a cysteine-free hinge region between domain 2 and 3, which is susceptible to proteolytic cleavage by matrix metalloproteinases (MMP) and other proteases (96). 


\section{Functions of CTGF}

The biological functions of CTGF are complex and diverse. Importantly, CTGF is required for most of the increased ECM production and other profibrotic activity generally observed in response to TGF- $\beta 1$ (97). In addition, CTGF is critically involved in cell growth and differentiation, migration, adherence, apoptosis and survival, as well as in angiogenesis and chondrogenesis (98). Specific direct effects of CTGF on renal cells include migration, hypertrophy, fibronectin production, and actin disassembly in mesangial cells, EMT and fibronectin production of tubular epithelial cells, and collagen type III and TSP-1 production by renal interstitial fibroblasts (99-104). Recently, a physiological role for CTGF has been demonstrated in human corneal epithelial cells, in which CTGF was required for regulation of reepithelialization (105).

Given its many and distinct interaction domains, it seems likely that CTGF functions mainly as an extracellular modulator of signaling activity of other growth factors. For instance, upon binding of domain 1 to IGF-1, CTGF and IGF1 act synergistically to induce collagen type I and type III production by renal interstitial fibroblasts (106). In contrast, binding of CTGF to BMP-4 results in inhibition of BMP-4 signaling activity (83). Binding of CTGF to VEGF via domain 3 results in inhibition of VEGF-induced angiogenesis, and this binding and inhibition are both lost upon cleavage of the CTGF hinge region by MMP-1, -3 , and -13 (96). Binding of CTGF domain 3 to LRP-1 results in activation of ERK1/2 MAPK signaling, which can be inhibited by the LRP-1 antagonist receptor-associated protein (107). Furthermore, simultaneous interaction of CTGF with HSPG and integrins is essential for its role in adherence and migration, and binding of CTGF domain 4 to LRP-6 suppresses Wntsignaling $(92,108)$. Also, binding of CTGF to fibronectin via domain 1 and domain 4 is important for the function of CTGF in cell-matrix interactions $(88,94)$.

\section{Synergy between CTGF and TGF- $\beta 1$}

CTGF is not only induced by TGF- $\beta 1$, but it is also a major enhancer of the biological activity of TGF- $\beta 1$. For example, persistence of skin fibrosis in newborn mice was achieved only after co-injection of both TGF- $\beta 1$ and CTGF, and not after injection of TGF- $\beta 1$ or CTGF alone (109). Anchorage-independent growth of rat fibroblasts and collagen synthesis were also dependent on both TGF- $\beta 1$ and CTGF (110,111).

The synergy between CTGF and TGF- $\beta 1$ might be explained by several mechanisms (Fig. 2). In the first place, physical interaction between TGF- $\beta 1$ and domain 2 of CTGF enhanced receptor binding and potentiated Smad-signaling activity of TGF- $\beta 1$ (83). In addition, binding to TrkA and induction of TIEG, presumably by domain 4 of CTGF, might interrupt the negative feedback loop of TGF- $\beta 1$, since Smad7, the major inhibitory Smad of the TGF- $\beta 1$ signaling pathway, is suppressed by TIEG (95). Finally, binding of CTGF domain 3 to LRP-1 enhanced TGF- $\beta 1$ responses, including myofibroblast activation, de novo expression of $\alpha$ smooth muscle actin, and extracellular accumulation of fibronectin. Remarkably, the latter effects were mediated by

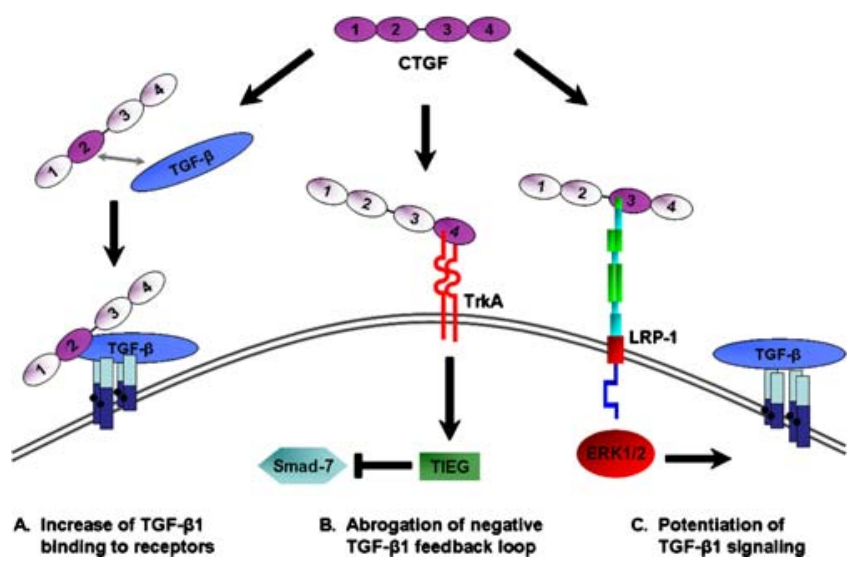

Fig. 2. Mechanisms behind the synergy between CTGF and TGF- $\beta 1$. A Direct binding of TGF- $\beta 1$ to domain 2 of CTGF enhances receptor binding and potentiates signaling activity of TGF- $\beta 1$ (83). B Direct binding of CTGF, presumably via domain 4, to TrkA leads to induction of TIEG with subsequent inhibition of Smad7, the major inhibitory Smad of the TGF- $\beta 1$ signaling pathway (95). Loss of inhibitory Smad7 activity would lead to enhanced TGF- $\beta 1$ signaling activity. C Binding of CTGF domain 3 to LRP-1 enhances TGF- $\beta 1$ responses by ERK1/2 MAPK activation (107).

ERK1/2 MAPK activation, without any evident modulation of TGF- $\beta 1$ induced phosphorylation of Smad2, or of pSmad2/ 3 association with Smad4 (107).

It remains to be established whether synergy between TGF- $\beta 1$, TrkA, and LRP-1 derives entirely from their individual interactions with separate CTGF domains per se. In addition, cross-talk resulting from simultaneous interaction of the distinct CTGF domains with their respective binding partners might be relevant. This would be of interest with respect to biological relevance of full length CTGF, as compared to physiologically occurring CTGF cleavage products.

\section{CTGF IS UPREGULATED IN RENAL FIBROSIS}

\section{CTGF Expression in Renal Fibrosis}

Although development of the kidney is not affected in $\mathrm{CTGF}^{-1-}$ mice (112), the expression of CTGF is more abundant in the normal adult kidney than in other organs (113). In control human renal biopsies, CTGF mRNA is mainly expressed in podocytes, and in some parietal epithelial cells and interstitial cells. However, in renal biopsies of patients with progressive glomerulopathies and tubulointerstitial damage, strong overexpression of glomerular and tubulointerstitial CTGF mRNA was reported, of which the latter correlated with the degree of damage (114). In experimental and human crescentic glomerulonephritis, CTGF was strongly overexpressed in areas with proliferating glomerular parietal epithelial cells $(115,116)$. Upregulation of CTGF was also observed in experimental models of lupus nephritis, anti-Thy-1.1-induced acute mesangial proliferative glomerulonephritis, UUO, hypertensive nephrosclerosis, and in the remnant kidney of 5/6 nephrectomized mice (117-121). Furthermore, CTGF is critically involved in chronic allograft nephropathy, in which CTGF expression was shown to be highly expressed in tubular epithelial cells of the transplanted 
kidney, and in serum and urine of renal transplant recipients $(122,123)$

\section{CTGF in Diabetic Nephropathy}

CTGF is considered to be of particular interest to diabetic nephropathy. Already soon after its identification, the expression of CTGF mRNA was shown to be strongly upregulated in human mesangial cells cultured under high glucose, and in renal biopsies of patients with diabetic nephropathy $(114,124)$. These observations were extended in rodent models of both type 1 and type 2 diabetic nephropathy $(104,125,126)$. Furthermore, severity of diabetic nephropathy was aggravated in transgenic mice with specific overexpression of CTGF in podocytes (127). Upregulation of CTGF was also confirmed in the diabetic myocardium, liver, retina, and aorta $(126,128-130)$. The potential use of CTGF as a biomarker for renal damage in diabetes was assessed in several clinical studies, in which soluble levels of CTGF were increased in plasma and urine of patients with diabetic nephropathy, and correlated with clinical markers of renal disease (131-134). Moreover, in renal biopsies of patients with type 2 diabetic nephropathy, tubular expression of CTGF correlated with proteinuria, serum creatinine, and interstitial fibrosis (135). Interestingly, CTGF expression was shown to be decreased in microdissected glomeruli from renal biopsies of patients with diabetic nephropathy, but this was probably related to loss of podocytes (136).

\section{Regulation of CTGF}

TGF- $\beta 1$ is the earliest recognized inducer of CTGF, and has remained one of the most studied regulators of CTGF expression in fibrotic processes $(97,137)$. In addition, in vitro studies with renal cells demonstrated that CTGF is also a direct target of gene regulation by TGF- $\beta 1$-independent factors including high glucose, angiotensin II, aldosterone, hypoxia inducible factor$1 \alpha$, and cyclic mechanical strain (124,125,138-141). The $3^{\prime}-$ untranslated region of CTGF gene also contains regulatory sequences, of which the activity depends on as yet largely unidentified factors $(142,143)$. In addition, several polymorphisms in the CTGF promoter region have been identified, which might contribute to genetic susceptibility of patients to develop fibrotic disorders (144-146). Of great interest, a G945C polymorphism in the promoter of CTGF was recently shown to be associated with susceptibility to systemic sclerosis (147). However, it remains to be established whether this polymorphism is also associated with increased levels of CTGF and susceptibility of patients to develop renal fibrosis.

\section{CTGF IS A TARGET FOR ANTIFIBROTIC THERAPY}

\section{Inhibition of CTGF}

CTGF is a downstream mediator of profibrotic TGF- $\beta 1$ activity, and although one report has proposed a role of CTGF in mediating TGF- $\beta 1$ induced apoptosis in a breast cancer cell line (148), there are no other reports of CTGF involvement in the beneficial functions of TGF- $\beta 1$ in anti- inflammation and tumor suppression. In addition, restoration of the balance between TGF- $\beta 1$ and BMP signaling activity seems more attractive than interference in a pathway that also includes beneficial effects. Therefore, targeting CTGF in fibrotic disorders, and renal fibrosis in particular, has been proposed as a more suitable approach for antifibrotic intervention than direct targeting of TGF- $\beta 1(149,150)$.

In vitro, EMT of tubular epithelial cells could be inhibited both by a homologous hexadeca-peptide of domain 4 of CTGF that recognizes $\alpha \mathrm{v} \beta 3$, and by CTGF knockdown with antisense oligodeoxynucleotides (ODN) (151,152). CTGF antisense ODN treatment also effectively reduced expression of ECM genes and tubulointerstitial fibrosis in experimental renal diseases, including UUO, the remnant kidney model in TGF- $\beta 1$ overexpressing mice, and in dexamethasone-induced nephropathy (153-155).

\section{CTGF Therapy in Diabetic Nephropathy}

Recently, treatment with CTGF antisense ODN proved to be successful in attenuation of proteinuria, and in reduction of genes involved in mesangial matrix expansion in mouse models of type 1 and type 2 diabetes (156). Interestingly, reduction of albuminuria was also observed in diabetic $\mathrm{db} / \mathrm{db}$ mice treated with CTGF neutralizing antibody, and in diabetic $\mathrm{CTGF}^{+/-}$ mice harboring only one functional CTGF allele. These latter two studies also showed that inhibition of CTGF in diabetic nephropathy resulted in reduced thickening of the glomerular basement membrane (Flyvbjerg et al., abstract J Am Soc Nephrol 15:261A, 2004, and Nguyen et al., submitted). AntiCTGF treatment also reversed vascular stiffness and microvascular leakage, improved cardiac function, and normalized hypertension in type 1 diabetic rats (Langsetmo et al., abstract Diabetes 55:A122, 2006). Moreover, a fully human anti-CTGF antibody (FG3019) has been tested for safety in phase 1 clinical trials in microalbuminuric type 1 and type 2 diabetic patients. Administration of the antibody proved to be well tolerated and was able to decrease urinary albumin to creatinine ratio by $50 \%$ or more in 7 of 19 subjects (Adler et al., abstract J Am Soc Nephrol 15:TH-PO239, 2004).

\section{CONCLUSION}

Renal fibrosis is the major determinant in progression of acute and chronic kidney disease. TGF- $\beta 1$ is the driving force behind renal fibrosis and has since long been regarded as the key factor to be targeted in prevention and treatment of renal fibrosis. Considering its multiple effects, which are in part also protective and beneficial, direct inhibition of general TGF- $\beta 1$ activity might not be clinically applicable. Recently, BMP-7 and CTGF have emerged as novel modulators of profibrotic TGF- $\beta 1$ activity. In experimental models of renal disease, especially in diabetic nephropathy, either administration of BMP-7 or inhibition of CTGF have been sufficient to result in striking improvement of renal function and structure. Targeting the profibrotic activity of both growth factors might occur at several levels of their pathophysiological interaction with other mediators, extracellular matrix, and cell surface molecules. However, for both candidate therapeutics, assessment of clinical applicability is still in an early phase of testing. 


\section{ACKNOWLEDGMENTS}

This work is supported by the Netherlands Organization for Scientific Research (Mozaiek grant 017.003.037) and by the Dutch Kidney Foundation (C05.2144). RG has received research support grants and consulting fees from FibroGen, Inc.

Open Access This article is distributed under the terms of the Creative Commons Attribution Noncommercial License which permits any noncommercial use, distribution, and reproduction in any medium, provided the original author(s) and source are credited.

\section{REFERENCES}

1. F. Strutz, and G. A. Muller. Renal fibrosis and the origin of the renal fibroblast. Nephrol. Dial. Transplant. 21:3368-3370 (2006).

2. R. Kalluri, and E. G. Neilson. Epithelial-mesenchymal transition and its implications for fibrosis. J. Clin. Invest. 112:17761784 (2003)

3. E. P. Bottinger, and M. Bitzer. TGF-beta signaling in renal disease. J. Am. Soc. Nephrol. 13:2600-2610 (2002).

4. Y. Liu. Renal fibrosis: new insights into the pathogenesis and therapeutics. Kidney Int. 69:213-217 (2006).

5. D. M. Kingsley. The TGF-beta superfamily: new members, new receptors, and new genetic tests of function in different organisms. Genes Dev. 8:133-146 (1994).

6. K. Miyazono, K. Kusanagi, and H. Inoue. Divergence and convergence of TGF-beta/BMP signaling. J. Cell. Physiol. 187:265-276 (2001).

7. M. Bitzer, R. B. Sterzel, and E. P. Bottinger. Transforming growth factor-beta in renal disease. Kidney Blood Press. Res. 21:1-12 (1998).

8. H. L. Moses, E. Y. Yang, and J. A. Pietenpol. TGF-beta stimulation and inhibition of cell proliferation: new mechanistic insights. Cell 63:245-247 (1990).

9. A. B. Roberts, and M. B. Sporn. Physiological actions and clinical applications of transforming growth factor-beta (TGFbeta). Growth Factors 8:1-9 (1993).

10. S. M. Wahl, D. A. Hunt, H. L. Wong, S. Dougherty, N. CartneyFrancis, L. M. Wahl, L. Ellingsworth, J. A. Schmidt, G. Hall, and A. B. Roberts. Transforming growth factor-beta is a potent immunosuppressive agent that inhibits IL-1-dependent lymphocyte proliferation. J. Immunol. 140:3026-3032 (1988).

11. W. A. Border, S. Okuda, L.R. Languino, M. B. Sporn, and E. Ruoslahti. Suppression of experimental glomerulonephritis by antiserum against transforming growth factor beta 1. Nature 346:371-374 (1990).

12. A. Hamaguchi, S. Kim, K. Ohta, K. Yagi, T. Yukimura, K. Miura, T. Fukuda, and H. Iwao. Transforming growth factorbeta 1 expression and phenotypic modulation in the kidney of hypertensive rats. Hypertension 26:199-207 (1995).

13. T. Coimbra, R. Wiggins, J. W. Noh, S. Merritt, and S. H. Phan. Transforming growth factor-beta production in anti-glomerular basement membrane disease in the rabbit. Am. J. Pathol. 138:223-234 (1991).

14. H. Kaneto, J. Morrissey, and S. Klahr. Increased expression of TGF-beta 1 mRNA in the obstructed kidney of rats with unilateral ureteral ligation. Kidney Int. 44:313-321 (1993).

15. T. Yamamoto, T. Nakamura, N. A. Noble, E. Ruoslahti, and W. A. Border. Expression of transforming growth factor beta is elevated in human and experimental diabetic nephropathy. Proc. Natl. Acad. Sci. U. S. A. 90:1814-1818 (1993).

16. K. Yoshioka, T. Takemura, K. Murakami, M. Okada, S. Hino, H. Miyamoto, and S. Maki. Transforming growth factor-beta protein and mRNA in glomeruli in normal and diseased human kidneys. Lab. Invest. 68:154-163 (1993).

17. T. Yamamoto, N. A. Noble, A. H. Cohen, C. C. Nast, A. Hishida, L. I. Gold, and W. A. Border. Expression of transforming growth factor-beta isoforms in human glomerular diseases. Kidney Int. 49:461-469 (1996).

18. B. M. Coupes, C. G. Newstead, C. D. Short, and P. E. Brenchley. Transforming growth factor beta 1 in renal allograft recipients. Transplantation 57:1727-1731 (1994).

19. H. Kanai, H. Mitsuhashi, K. Ono, S. Yano, and T. Naruse. Increased excretion of urinary transforming growth factor beta in patients with focal glomerular sclerosis. Nephron 66:391-395 (1994).

20. A. Pfeiffer, K. Middelberg-Bisping, C. Drewes, and H. Schatz. Elevated plasma levels of transforming growth factor-beta 1 in NIDDM. Diabetes Care 19:1113-1117 (1996).

21. K. Sharma, Y. Jin, J. Guo, and F. N. Ziyadeh. Neutralization of TGF-beta by anti-TGF-beta antibody attenuates kidney hypertrophy and the enhanced extracellular matrix gene expression in STZ-induced diabetic mice. Diabetes 45:522-530 (1996).

22. Y. Akagi, Y. Isaka, M. Arai, T. Kaneko, M. Takenaka, T. Moriyama, Y. Kaneda, A. Ando, Y. Orita, T. Kamada, N. Ueda, and E. Imai. Inhibition of TGF-beta 1 expression by antisense oligonucleotides suppressed extracellular matrix accumulation in experimental glomerulonephritis. Kidney Int. 50:148-155 (1996).

23. W. A. Border, N. A. Noble, T. Yamamoto, J. R. Harper, Y. Yamaguchi, M. D. Pierschbacher, and E. Ruoslahti. Natural inhibitor of transforming growth factor-beta protects against scarring in experimental kidney disease. Nature 360:361-364 (1992).

24. Y. Isaka, Y. Akagi, Y. Ando, M. Tsujie, T. Sudo, N. Ohno, W. A. Border, N. A. Noble, Y. Kaneda, M. Hori, and E. Imai. Gene therapy by transforming growth factor-beta receptorIgG Fc chimera suppressed extracellular matrix accumulation in experimental glomerulonephritis. Kidney Int. 55:465-475 (1999).

25. J. A. Moon, H. T. Kim, I. S. Cho, Y. Y. Sheen, and D. K. Kim. IN-1130, a novel transforming growth factor-beta type I receptor kinase (ALK5) inhibitor, suppresses renal fibrosis in obstructive nephropathy. Kidney Int. 70:1234-1243 (2006).

26. E. T. Grygielko, W. M. Martin, C. Tweed, P. Thornton, J. Harling, D. P. Brooks, and N. J. Laping. Inhibition of gene markers of fibrosis with a novel inhibitor of transforming growth factor-beta type I receptor kinase in puromycin-induced nephritis. J. Pharmacol. Exp. Ther. 313:943-951 (2005).

27. M. Petersen, M. Thorikay, M. Deckers, D. M. van, E. T. Grygielko, F. Gellibert, A. C. De Gouville, S. Huet, D. P. Ten, and N. J. Laping. Oral administration of GW788388, an inhibitor of TGF-beta type I and II receptor kinases, decreases renal fibrosis. Kidney Int. DOI 10.1038/sj.ki.5002717 (2007).

28. A. B. Kulkarni, C. G. Huh, D. Becker, A. Geiser, M. Lyght, K. C. Flanders, A. B. Roberts, M. B. Sporn, J. M. Ward, and S. Karlsson. Transforming growth factor beta 1 null mutation in mice causes excessive inflammatory response and early death. Proc. Natl. Acad. Sci. U. S. A. 90:770-774 (1993).

29. W. Wang, X. R. Huang, A. G. Li, F. Liu, J. H. Li, L. D. Truong, X. J. Wang, and H. Y. Lan. Signaling mechanism of TGF-beta1 in prevention of renal inflammation: role of Smad7. J. Am. Soc. Nephrol. 16:1371-1383 (2005).

30. B. Tang, E. P. Bottinger, S. B. Jakowlew, K. M. Bagnall, J. Mariano, M. R. Anver, J. J. Letterio, and L. M. Wakefield. Transforming growth factor-beta1 is a new form of tumor suppressor with true haploid insufficiency. Nat. Med. 4:802-807 (1998).

31. B. Tang, C. K. de Castro, H. E. Barnes, W. T. Parks, L. Stewart, E. P. Bottinger, D. Danielpour, and L. M. Wakefield. Loss of responsiveness to transforming growth factor beta induces malignant transformation of nontumorigenic rat prostate epithelial cells. Cancer Res. 59:4834-4842 (1999).

32. A. T. Dudley, K. M. Lyons, and E. J. Robertson. A requirement for bone morphogenetic protein-7 during development of the mammalian kidney and eye. Genes Dev. 9:27952807 (1995). 
33. A. Raatikainen-Ahokas, M. Hytonen, A. Tenhunen, K. Sainio, and H. Sariola. BMP-4 affects the differentiation of metanephric mesenchyme and reveals an early anteriorposterior axis of the embryonic kidney. Dev. Dyn. 217:146158 (2000).

34. A. T. Dudley, and E. J. Robertson. Overlapping expression domains of bone morphogenetic protein family members potentially account for limited tissue defects in BMP7 deficient embryos. Dev. Dyn. 208:349-362 (1997).

35. R. E. Godin, E. J. Robertson, and A. T. Dudley. Role of BMP family members during kidney development. Int. J. Dev. Biol. 43:405-411 (1999).

36. S. E. Gould, M. Day, S. S. Jones, and H. Dorai. BMP-7 regulates chemokine, cytokine, and hemodynamic gene expression in proximal tubule cells. Kidney Int. 61:51-60 (2002).

37. M. M. Almanzar, K. S. Frazier, P. H. Dube, A. I. Piqueras, W. K. Jones, M. F. Charette, and A. L. Paredes. Osteogenic protein-1 mRNA expression is selectively modulated after acute ischemic renal injury. J. Am. Soc. Nephrol. 9:1456-1463 (1998).

38. M. Simon, J. G. Maresh, S. E. Harris, J. D. Hernandez, M. Arar, M. S. Olson, and H. E. Abboud. Expression of bone morphogenetic protein-7 mRNA in normal and ischemic adult rat kidney. Am. J. Physiol. 276:F382-F389 (1999).

39. K. A. Hruska, G. Guo, M. Wozniak, D. Martin, S. Miller, H. Liapis, K. Loveday, S. Klahr, T. K. Sampath, and J. Morrissey. Osteogenic protein-1 prevents renal fibrogenesis associated with ureteral obstruction. Am. J. Physiol. Renal. Physiol. 279: F130-F143 (2000).

40. N. K. Biyikli, H. Tugtepe, F. Cakalagaoglu, A. Ilki, and H. Alpay. Downregulation of the expression of bone morphogenetic protein 7 in experimental pyelonephritis. Pediatr. Nephrol. 20:1230-1236 (2005).

41. B. Ogutmen, S. Tuglular, F. Cakalagaoglu, C. Ozener, and E. Akoglu. Transforming growth factor-beta1, vascular endothelial growth factor, and bone morphogenic protein-7 expression in tacrolimus-induced nephrotoxicity in rats. Transplant. Proc. 38:487-489 (2006).

42. S. Tuglular, Y. D. Gogas, F. Cakalagaoglu, L. Citak, H. Arikan, H. Kocak, C. Ozener, and E. Akoglu. Cyclosporine-A induced nephrotoxicity is associated with decreased renal bone morphogenetic protein-7 expression in rats. Transplant. Proc. 36:131-133 (2004).

43. M. Zeisberg, C. Bottiglio, N. Kumar, Y. Maeshima, F. Strutz, G. A. Muller, and R. Kalluri. Bone morphogenic protein-7 inhibits progression of chronic renal fibrosis associated with two genetic mouse models. Am. J. Physiol. Renal. Physiol. 285: F1060-F1067 (2003).

44. S. N. Wang, J. Lapage, and R. Hirschberg. Loss of tubular bone morphogenetic protein-7 in diabetic nephropathy. J. Am. Soc. Nephrol. 12:2392-2399 (2001).

45. G. M. Mitu, S. Wang, and R. Hirschberg. BMP7 is a podocyte survival factor and rescues podocytes from diabetic injury. Am. J. Physiol. Renal. Physiol. 293:F1641-F1648 (2007).

46. L. De Petris, K. A. Hruska, S. Chiechio, and H. Liapis. Bone morphogenetic protein-7 delays podocyte injury due to high glucose. Nephrol. Dial. Transplant. 22:3442-3450 (2007).

47. M. Zeisberg, J. Hanai, H. Sugimoto, T. Mammoto, D. Charytan, F. Strutz, and R. Kalluri. BMP-7 counteracts TGF-beta1induced epithelial-to-mesenchymal transition and reverses chronic renal injury. Nat. Med. 9:964-968 (2003).

48. S. Wang, C. M. de Caestecker, J. Kopp, G. Mitu, J. Lapage, and R. Hirschberg. Renal bone morphogenetic protein-7 protects against diabetic nephropathy. J. Am. Soc. Nephrol. 17:25042512 (2006).

49. M. Zeisberg, G. A. Muller, and R. Kalluri. Are there endogenous molecules that protect kidneys from injury? The case for bone morphogenic protein-7 (BMP-7). Nephrol. Dial. Transplant. 19:759-761 (2004).

50. X. L. Zhang, W. Selbi, M. C. de la Motte, V. Hascall, and A. O. Phillips. Bone morphogenic protein-7 inhibits monocyte-stimulated TGF-beta1 generation in renal proximal tubular epithelial cells. J. Am. Soc. Nephrol. 16:79-89 (2005).

51. M. Li, K. S. Hering-Smith, E. E. Simon, and V. Batuman. Myeloma light chains induce epithelial mesenchymal transition in human renal proximal tubule epithelial cells. Nephrol. Dial. Transplant. DOI 10.1093/ndt/gfm670 (2007).

52. S. Wang, and R. Hirschberg. BMP7 antagonizes TGF-beta dependent fibrogenesis in mesangial cells. Am. J. Physiol. Renal. Physiol. 284:F1006-F1013 (2003).

53. H. Otani, F. Otsuka, K. Inagaki, M. Takeda, T. Miyoshi, J. Suzuki, T. Mukai, T. Ogura, and H. Makino. Antagonistic effects of bone morphogenetic protein- 4 and -7 on renal mesangial cell proliferation induced by aldosterone through MAPK activation. Am. J. Physiol. Renal. Physiol. 292:F1513F1525 (2007).

54. M. Zeisberg, A. A. Shah, and R. Kalluri. Bone morphogenic protein-7 induces mesenchymal to epithelial transition in adult renal fibroblasts and facilitates regeneration of injured kidney. J. Biol. Chem. 280:8094-8100 (2005).

55. S. Vukicevic, V. Basic, D. Rogic, N. Basic, M. S. Shih, A. Shepard, D. Jin, B. Dattatreyamurty, W. Jones, H. Dorai, S Ryan, D. Griffiths, J. Maliakal, M. Jelic, M. Pastorcic, A Stavljenic, and T. K. Sampath. Osteogenic protein-1 (bone morphogenetic protein-7) reduces severity of injury after ischemic acute renal failure in rat. J. Clin. Invest. 102:202-214 (1998).

56. J. Morrissey, K. Hruska, G. Guo, S. Wang, Q. Chen, and S. Klahr. Bone morphogenetic protein-7 improves renal fibrosis and accelerates the return of renal function. J. Am. Soc. Nephrol. 13(Suppl 1):S14-S21 (2002).

57. S. Wang, Q. Chen, T. C. Simon, F. Strebeck, L. Chaudhary, J. Morrissey, H. Liapis, S. Klahr, and K. A. Hruska. Bone morphogenic protein-7 (BMP-7), a novel therapy for diabetic nephropathy. Kidney Int. 63:2037-2049 (2003).

58. H. Sugimoto, G. Grahovac, M. Zeisberg, and R. Kalluri. Renal fibrosis and glomerulosclerosis in a new mouse model of diabetic nephropathy and its regression by bone morphogenic protein-7 and advanced glycation end product inhibitors. Diabetes 56:1825-1833 (2007).

59. H. Sugimoto, C. Yang, V. S. LeBleu, M. A. Soubasakos, M. Giraldo, M. Zeisberg, and R. Kalluri. BMP-7 functions as a novel hormone to facilitate liver regeneration. FASEB $J$. 21:256-264 (2007).

60. M. Zeisberg, C. Yang, M. Martino, M. B. Duncan, F. Rieder, H. Tanjore, and R. Kalluri. Fibroblasts derive from hepatocytes in liver fibrosis via epithelial to mesenchymal transition. J. Biol. Chem. 282:23337-23347 (2007).

61. F. Tacke, E. Gabele, F. Bataille, R. F. Schwabe, C. Hellerbrand, F. Klebl, R. H. Straub, T. Luedde, M. P. Manns, C. Trautwein, D. A. Brenner, J. Scholmerich, and B. Schnabl. Bone morphogenetic protein 7 is elevated in patients with chronic liver disease and exerts fibrogenic effects on human hepatic stellate cells. Dig. Dis. Sci. 52:3404-3415 (2007).

62. I. Maric, L. Poljak, S. Zoricic, D. Bobinac, D. Bosukonda, K. T. Sampath, and S. Vukicevic. Bone morphogenetic protein-7 reduces the severity of colon tissue damage and accelerates the healing of inflammatory bowel disease in rats. J. Cell. Physiol. 196:258-264 (2003).

63. E. M. Zeisberg, O. Tarnavski, M. Zeisberg, A. L. Dorfman, J. R. McMullen, E. Gustafsson, A. Chandraker, X. Yuan, W. T. $\mathrm{Pu}$, A. B. Roberts, E. G. Neilson, M. H. Sayegh, S. Izumo, and R. Kalluri. Endothelial-to-mesenchymal transition contributes to cardiac fibrosis. Nat. Med. 13:952-961 (2007).

64. R. J. Lund, M. R. Davies, A. J. Brown, and K. A. Hruska. Successful treatment of an adynamic bone disorder with bone morphogenetic protein-7 in a renal ablation model. J. Am. Soc. Nephrol. 15:359-369 (2004).

65. E. A. Gonzalez, R. J. Lund, K. J. Martin, J. E. McCartney, M. M. Tondravi, T. K. Sampath, and K. A. Hruska. Treatment of a murine model of high-turnover renal osteodystrophy by exogenous BMP-7. Kidney Int. 61:1322-1331 (2002).

66. M. R. Davies, R. J. Lund, and K. A. Hruska. BMP-7 is an efficacious treatment of vascular calcification in a murine model of atherosclerosis and chronic renal failure. J. Am. Soc. Nephrol. 14:1559-1567 (2003).

67. A. P. White, A. R. Vaccaro, J. A. Hall, P. G. Whang, B. C. Friel, and M. D. McKee. Clinical applications of BMP-7/OP-1 in fractures, nonunions and spinal fusion. Int. Orthop. 31:735-741 (2007). 
68. C. Daniel, K. Schaub, K. Amann, J. Lawler, and C. Hugo. Thrombospondin-1 is an endogenous activator of TGF-beta in experimental diabetic nephropathy in vivo. Diabetes 56:29822989 (2007).

69. O. V. Volpert, R. Pili, H. A. Sikder, T. Nelius, T. Zaichuk, C. Morris, C. B. Shiflett, M. K. Devlin, K. Conant, and R. M. Alani. Id1 regulates angiogenesis through transcriptional repression of thrombospondin-1. Cancer Cell 2:473-483 (2002).

70. L. Oxburgh, A. T. Dudley, R. E. Godin, C. H. Koonce, A. Islam, D. C. Anderson, E. K. Bikoff, and E. J. Robertson. BMP4 substitutes for loss of BMP7 during kidney development. Dev. Biol. 286:637-646 (2005).

71. T. Q. Nguyen, H. Chon, F. A. van Nieuwenhoven, B. Braam, M. C. Verhaar, and R. Goldschmeding. Myofibroblast progenitor cells are increased in number in patients with type 1 diabetes and express less bone morphogenetic protein 6: a novel clue to adverse tissue remodelling? Diabetologia 49:1039-1048 (2006).

72. T. Yabe, I. Samuels, and J. P. Schwartz. Bone morphogenetic proteins BMP-6 and BMP-7 have differential effects on survival and neurite outgrowth of cerebellar granule cell neurons. $J$. Neurosci. Res. 68:161-168 (2002).

73. T. D. Piscione, T. D. Yager, I. R. Gupta, B. Grinfeld, Y. Pei, L. Attisano, J. L. Wrana, and N. D. Rosenblum. BMP-2 and OP-1 exert direct and opposite effects on renal branching morphogenesis. Am. J. Physiol. 273:F961-F975 (1997).

74. X. Li, H. Y. Yang, and C. M. Giachelli. BMP-2 promotes phosphate uptake, phenotypic modulation, and calcification of human vascular smooth muscle cells. Atherosclerosis. DOI 10.1016/j.atherosclerosis.2007.11.031 (2008).

75. L. Mikhaylova, J. Malmquist, and M. Nurminskaya. Regulation of in vitro vascular calcification by BMP4, VEGF and Wnt3a. Calcif Tissue Int. 81:372-381 (2007).

76. J. Lin, S. R. Patel, X. Cheng, E. A. Cho, I. Levitan, M. Ullenbruch, S. H. Phan, J. M. Park, and G. R. Dressler. Kielin/ chordin-like protein, a novel enhancer of BMP signaling, attenuates renal fibrotic disease. Nat. Med. 11:387-393 (2005).

77. J. Lin, S. R. Patel, M. Wang, and G. R. Dressler. The cysteinerich domain protein $\mathrm{KCP}$ is a suppressor of transforming growth factor beta/activin signaling in renal epithelia. Mol. Cell. Biol. 26:4577-4585 (2006).

78. M. Yanagita, T. Okuda, S. Endo, M. Tanaka, K. Takahashi, F. Sugiyama, S. Kunita, S. Takahashi, A. Fukatsu, M. Yanagisawa, T. Kita, and T. Sakurai. Uterine sensitization-associated gene-1 (USAG-1), a novel BMP antagonist expressed in the kidney, accelerates tubular injury. J. Clin. Invest. 116:70-79 (2006).

79. M. Tanaka, S. Endo, T. Okuda, A. N. Economides, D. M. Valenzuela, A. J. Murphy, E. Robertson, T. Sakurai, A. Fukatsu, G. D. Yancopoulos, T. Kita, and M. Yanagita. Expression of BMP-7 and USAG-1 (a BMP antagonist) in kidney development and injury. Kidney Int. 73:181-191 (2008).

80. K. R. Blish, W. Wang, M. C. Willingham, W. Du, C. E. Birse, S. R. Krishnan, J. C. Brown, G. A. Hawkins, A. J. Garvin, R. B. D'Agostino, Jr., F. M. Torti, and S. V. Torti. A Human Bone Morphogenetic Protein Antagonist is Down-Regulated in Renal Cancer. Mol. Biol. Cell. DOI 10.1091/mbc.E07-05-0433 (2007).

81. V. Dolan, M. Murphy, D. Sadlier, D. Lappin, P. Doran, C. Godson, F. Martin, Y. O'Meara, H. Schmid, A. Henger, M. Kretzler, A. Droguett, S. Mezzano, and H. R. Brady. Expression of gremlin, a bone morphogenetic protein antagonist, in human diabetic nephropathy. Am. J. Kidney Dis. 45:1034-1039 (2005).

82. Y. Miyazaki, H. Ueda, T. Yokoo, Y. Utsunomiya, T. Kawamura, T. Matsusaka, I. Ichikawa, and T. Hosoya. Inhibition of endogenous BMP in the glomerulus leads to mesangial matrix expansion. Biochem. Biophys. Res. Commun. 340:681-688 (2006).

83. J. G. Abreu, N. I. Ketpura, B. Reversade, and E. M. De Robertis. Connective-tissue growth factor (CTGF) modulates cell signalling by BMP and TGF-beta. Nat. Cell. Biol. 4:599-604 (2002).

84. D. M. Bradham, A. Igarashi, R. L. Potter, and G. R. Grotendorst. Connective tissue growth factor: a cysteine-rich mitogen secreted by human vascular endothelial cells is related to the SRC-induced immediate early gene product CEF-10. $J$. Cell. Biol. 114:1285-1294 (1991).
85. D. R. Brigstock, R. Goldschmeding, K. I. Katsube, S. C. Lam, L. F. Lau, K. Lyons, C. Naus, B. Perbal, B. Riser, M. Takigawa, and $\mathrm{H}$. Yeger. Proposal for a unified $\mathrm{CCN}$ nomenclature. Mol. Pathol. 56:127-128 (2003).

86. B. Perbal. CCN proteins: multifunctional signalling regulators. Lancet 363:62-64 (2004).

87. H. S. Kim, S. R. Nagalla, Y. Oh, E. Wilson, C. T. Roberts Jr., and R. G. Rosenfeld. Identification of a family of low-affinity insulin-like growth factor binding proteins (IGFBPs): characterization of connective tissue growth factor as a member of the IGFBP superfamily. Proc. Natl. Acad. Sci. U. S. A. 94:1298112986 (1997).

88. L. Pi, X. Ding, M. Jorgensen, J. J. Pan, S. H. Oh, D. Pintilie, A. Brown, W. Y. Song, and B. E. Petersen. Connective tissue growth factor with a novel fibronectin binding site promotes cell adhesion and migration during rat oval cell activation. Hepatology. DOI 10.1002/hep.22079 (2007).

89. P. R. Segarini, J. E. Nesbitt, D. Li, L. G. Hays, J. R. Yates III, and D. F. Carmichael. The low density lipoprotein receptorrelated protein/alpha2-macroglobulin receptor is a receptor for connective tissue growth factor. J. Biol. Chem. 276:40659-40667 (2001).

90. E. C. Heng, Y. Huang, S. A. Black Jr., and P. C. Trackman. $\mathrm{CCN} 2$, connective tissue growth factor, stimulates collagen deposition by gingival fibroblasts via module 3 and alpha6and beta1 integrins. J. Cell. Biochem. 98:409-420 (2006).

91. I. Inoki, T. Shiomi, G. Hashimoto, H. Enomoto, H. Nakamura, K. Makino, E. Ikeda, S. Takata, K. Kobayashi, and Y. Okada. Connective tissue growth factor binds vascular endothelial growth factor (VEGF) and inhibits VEGF-induced angiogenesis. FASEB J. 16:219-221 (2002).

92. R. Gao, and D. R. Brigstock. Connective tissue growth factor (CCN2) induces adhesion of rat activated hepatic stellate cells by binding of its $\mathrm{C}$-terminal domain to integrin alpha(v)beta(3) and heparan sulfate proteoglycan. J. Biol. Chem. 279:8848-8855 (2004).

93. S. Mercurio, B. Latinkic, N. Itasaki, R. Krumlauf, and J. C. Smith. Connective-tissue growth factor modulates WNT signalling and interacts with the WNT receptor complex. Development 131:2137-2147 (2004).

94. M. Hoshijima, T. Hattori, M. Inoue, D. Araki, H. Hanagata, A. Miyauchi, and M. Takigawa. CT domain of CCN2/CTGF directly interacts with fibronectin and enhances cell adhesion of chondrocytes through integrin alpha5beta1. FEBS Lett. 580:1376-1382 (2006).

95. N. A. Wahab, B. S. Weston, and R. M. Mason. Connective tissue growth factor $\mathrm{CCN} 2$ interacts with and activates the tyrosine kinase receptor TrkA. J. Am. Soc. Nephrol. 16:340-351 (2005).

96. G. Hashimoto, I. Inoki, Y. Fujii, T. Aoki, E. Ikeda, and Y. Okada. Matrix metalloproteinases cleave connective tissue growth factor and reactivate angiogenic activity of vascular endothelial growth factor 165. J. Biol. Chem. 277:36288-36295 (2002).

97. A. Leask, and D. J. Abraham. TGF-beta signaling and the fibrotic response. FASEB J. 18:816-827 (2004).

98. A. Leask, and D. J. Abraham. All in the CCN family: essential matricellular signaling modulators emerge from the bunker. $J$. Cell. Sci. 119:4803-4810 (2006)

99. I. E. Blom, A. J. van Dijk, L. Wieten, K. Duran, Y. Ito, L. Kleij, M. deNichilo, T. J. Rabelink, J. J. Weening, J. Aten, and R. Goldschmeding. In vitro evidence for differential involvement of CTGF, TGFbeta, and PDGF-BB in mesangial response to injury. Nephrol. Dial Transplant. 16:1139-1148 (2001).

100. N. bdel-Wahab, B. S. Weston, T. Roberts, and R. M. Mason. Connective tissue growth factor and regulation of the mesangial cell cycle: role in cellular hypertrophy. J. Am. Soc. Nephrol. 13:2437-2445 (2002).

101. J. K. Crean, F. Furlong, D. Mitchell, E. McArdle, C. Godson, and F. Martin. Connective tissue growth factor/CCN2 stimulates actin disassembly through Akt/protein kinase B-mediated phosphorylation and cytoplasmic translocation of p27(Kip-1). FASEB J. 20:1712-1714 (2006).

102. W. C. Burns, S. M. Twigg, J. M. Forbes, J. Pete, C. Tikellis, V. Thallas-Bonke, M. C. Thomas, M. E. Cooper, and P. 
Kantharidis. Connective tissue growth factor plays an important role in advanced glycation end product-induced tubular epithelial-to-mesenchymal transition: implications for diabetic renal disease. J. Am. Soc. Nephrol. 17:2484-2494 (2006).

103. B. C. Liu, J. D. Zhang, X. L. Zhang, G. Q. Wu, and M. X. Li. Role of connective tissue growth factor (CTGF) module 4 in regulating epithelial mesenchymal transition (EMT) in HK-2 cells. Clin. Chim. Acta. 373:144-150 (2006).

104. S. Wang, M. deNichilo, C. Brubaker, and R. Hirschberg. Connective tissue growth factor in tubulointerstitial injury of diabetic nephropathy. Kidney Int. 60:96-105 (2001).

105. G. A. Secker, A. J. Shortt, E. Sampson, Q. P. Schwarz, G. S. Schultz, and J. T. Daniels. TGFbeta stimulated re-epithelialisation is regulated by CTGF and Ras/MEK/ERK signalling. Exp. Cell. Res. 314:131-142 (2008).

106. S. Lam, R. N. van der Geest, N. A. Verhagen, F. A. van Nieuwenhoven, I. E. Blom, J. Aten, R. Goldschmeding, M. R. Daha, and C. van Kooten. Connective tissue growth factor and IGF-I are produced by human renal fibroblasts and cooperate in the induction of collagen production by high glucose. Diabetes 52:2975-2983 (2003).

107. M. Yang, H. Huang, J. Li, D. Li, and H. Wang. Tyrosine phosphorylation of the LDL receptor-related protein (LRP) and activation of the ERK pathway are required for connective tissue growth factor to potentiate myofibroblast differentiation. FASEB J. 18:1920-1921 (2004).

108. L. F. Lau, and S. C. Lam. The CCN family of angiogenic regulators: the integrin connection. Exp. Cell. Res. 248:44-57 (1999).

109. A. Leask, S. Sa, A. Holmes, X. Shiwen, C. M. Black, and D. J. Abraham. The control of cen2 (ctgf) gene expression in normal and scleroderma fibroblasts. Mol. Pathol. 54:180-183 (2001)

110. D. Kothapalli, K. S. Frazier, A. Welply, P. R. Segarini, and G. R. Grotendorst. Transforming growth factor beta induces anchorage-independent growth of NRK fibroblasts via a connective tissue growth factor-dependent signaling pathway. Cell Growth Differ. 8:61-68 (1997).

111. M. R. Duncan, K. S. Frazier, S. Abramson, S. Williams, H. Klapper, X. Huang, and G. R. Grotendorst. Connective tissue growth factor mediates transforming growth factor beta-induced collagen synthesis: down-regulation by cAMP. FASEB $J$. 13:1774-1786 (1999).

112. S. Ivkovic, B. S. Yoon, S. N. Popoff, F. F. Safadi, D. E. Libuda, R. C. Stephenson, A. Daluiski, and K. M. Lyons. Connective tissue growth factor coordinates chondrogenesis and angiogenesis during skeletal development. Development 130:2779-2791 (2003).

113. B. S. Oemar, A. Werner, J. M. Garnier, D. D. Do, N. Godoy, M. Nauck, W. Marz, J. Rupp, M. Pech, and T. F. Luscher. Human connective tissue growth factor is expressed in advanced atherosclerotic lesions. Circulation 95:831-839 (1997).

114. Y. Ito, J. Aten, R. J. Bende, B. S. Oemar, T. J. Rabelink, J. J. Weening, and R. Goldschmeding. Expression of connective tissue growth factor in human renal fibrosis. Kidney Int. 53:853861 (1998).

115. K. Kanemoto, J. Usui, K. Nitta, S. Horita, A. Harada, A. Koyama, J. Aten, and M. Nagata. In situ expression of connective tissue growth factor in human crescentic glomerulonephritis. Virchows Arch. 444:257-263 (2004).

116. K. Kanemoto, J. Usui, S. Tomari, H. Yokoi, M. Mukoyama, J. Aten, J. J. Weening, and M. Nagata. Connective tissue growth factor participates in scar formation of crescentic glomerulonephritis. Lab. Invest. 83:1615-1625 (2003).

117. L. Bao, J. Zhou, V. M. Holers, and R. J. Quigg. Excessive matrix accumulation in the kidneys of MRL/lpr lupus mice is dependent on complement activation. J. Am. Soc. Nephrol. 14:2516-2525 (2003).

118. Y. Ito, R. Goldschmeding, R. Bende, N. Claessen, M. Chand, L. Kleij, T. Rabelink, J. Weening, and J. Aten. Kinetics of connective tissue growth factor expression during experimental proliferative glomerulonephritis. J. Am. Soc. Nephrol. 12:472484 (2001).

119. H. Yokoi, M. Mukoyama, A. Sugawara, K. Mori, T. Nagae, H. Makino, T. Suganami, K. Yahata, Y. Fujinaga, I. Tanaka, and K. Nakao. Role of connective tissue growth factor in fibronectin expression and tubulointerstitial fibrosis. Am. J. Physiol. Renal. Physiol. 282:F933-F942 (2002).

120. H. N. de las, M. Ruiz-Ortega, M. Ruperez, D. Sanz-Rosa, M. Miana, P. Aragoncillo, S. Mezzano, V. Lahera, J. Egido, and V. Cachofeiro. Role of connective tissue growth factor in vascular and renal damage associated with hypertension in rats. Interactions with angiotensin II. J. Renin Angiotensin Aldosterone Syst. 7:192-200 (2006).

121. T. Inoue, H. Okada, T. Kobayashi, Y. Watanabe, Y. Kanno, J. B. Kopp, T. Nishida, M. Takigawa, M. Ueno, T. Nakamura, and H. Suzuki. Hepatocyte growth factor counteracts transforming growth factor-beta1, through attenuation of connective tissue growth factor induction, and prevents renal fibrogenesis in $5 / 6$ nephrectomized mice. FASEB J. 17:268-270 (2003).

122. O. Cheng, R. Thuillier, E. Sampson, G. Schultz, P. Ruiz, X. Zhang, P. S. Yuen, and R. B. Mannon. Connective tissue growth factor is a biomarker and mediator of kidney allograft fibrosis. Am J Transplant. 6:2292-2306 (2006).

123. Z. Tu, Y. Shi, J. Wang, J. Bao, and H. Bu. Upregulation of connective tissue growth factor in a rat model of chronic allograft nephropathy. Nephrology (Carlton) 12:166-171 (2007).

124. M. Murphy, C. Godson, S. Cannon, S. Kato, H. S. Mackenzie, F. Martin, and H. R. Brady. Suppression subtractive hybridization identifies high glucose levels as a stimulus for expression of connective tissue growth factor and other genes in human mesangial cells. J. Biol. Chem. 274:5830-5834 (1999).

125. B. L. Riser, M. deNichilo, P. Cortes, C. Baker, J. M. Grondin, J. Yee, and R. G. Narins. Regulation of connective tissue growth factor activity in cultured rat mesangial cells and its expression in experimental diabetic glomerulosclerosis. J. Am. Soc. Nephrol. 11:25-38 (2000).

126. P. Roestenberg, F. A. van Nieuwenhoven, J. A. Joles, C. Trischberger, P. P. Martens, N. Oliver, J. Aten, J. W. Hoppener, and R. Goldschmeding. Temporal expression profile and distribution pattern indicate a role of connective tissue growth factor (CTGF/CCN-2) in diabetic nephropathy in mice. Am. $J$. Physiol. Renal. Physiol. 290:F1344-F1354 (2006).

127. H. Yokoi, M. Mukoyama, K. Mori, M. Kasahara, T. Suganami, K. Sawai, T. Yoshioka, Y. Saito, Y. Ogawa, T. Kuwabara, A. Sugawara, and K. Nakao. Overexpression of connective tissue growth factor in podocytes worsens diabetic nephropathy in mice. Kidney Int. DOI 10.1038/sj.ki.5002722 (2007).

128. K. J. Way, K. Isshiki, K. Suzuma, T. Yokota, D. Zvagelsky, F. J. Schoen, G. E. Sandusky, P. A. Pechous, C. J. Vlahos, H. Wakasaki, and G. L. King. Expression of connective tissue growth factor is increased in injured myocardium associated with protein kinase $\mathrm{C}$ beta2 activation and diabetes. Diabetes 51:2709-2718 (2002).

129. E. J. Kuiper, A. N. Witmer, I. Klaassen, N. Oliver, R. Goldschmeding, and R. O. Schlingemann. Differential expression of connective tissue growth factor in microglia and pericytes in the human diabetic retina. $\mathrm{Br}$. J. Ophthalmol. 88:1082-1087 (2004).

130. M. A. San, P. Du, A. Dikalova, B. Lassegue, M. Aleman, M. C. Gongora, K. Brown, G. Joseph, D. G. Harrison, W. R. Taylor, H. Jo, and K. K. Griendling. Reactive oxygen species-selective regulation of aortic inflammatory gene expression in type 2 diabetes. Am. J. Physiol. Heart Circ. Physiol. 292:H2073-H2082 (2007).

131. B. L. Riser, P. Cortes, M. deNichilo, P. V. Deshmukh, P. S. Chahal, A. K. Mohammed, J. Yee, and D. Kahkonen. Urinary CCN2 (CTGF) as a possible predictor of diabetic nephropathy: preliminary report. Kidney Int. 64:451-458 (2003).

132. R. E. Gilbert, A. Akdeniz, S. Weitz, W. R. Usinger, C. Molineaux, S. E. Jones, R. G. Langham, and G. Jerums. Urinary connective tissue growth factor excretion in patients with type 1 diabetes and nephropathy. Diabetes Care 26:26322636 (2003).

133. T. Q. Nguyen, L. Tarnow, S. Andersen, P. Hovind, H. H. Parving, R. Goldschmeding, and F. A. van Nieuwenhoven. Urinary connective tissue growth factor excretion correlates with clinical markers of renal disease in a large population of type 1 diabetic patients with diabetic nephropathy. Diabetes Care 29:83-88 (2006). 
134. P. Roestenberg, F. A. van Nieuwenhoven, L. Wieten, P. Boer, T. Diekman, A. M. Tiller, W. M. Wiersinga, N. Oliver, W. Usinger, S. Weitz, R. O. Schlingemann, and R. Goldschmeding. Connective tissue growth factor is increased in plasma of type 1 diabetic patients with nephropathy. Diabetes Care 27:1164-1170 (2004).

135. T. Kobayashi, H. Okada, T. Inoue, Y. Kanno, and H. Suzuki. Tubular expression of connective tissue growth factor correlates with interstitial fibrosis in type 2 diabetic nephropathy. Nephrol. Dial. Transplant. 21:548-549 (2006).

136. H. J. Baelde, M. Eikmans, D. W. Lappin, P. P. Doran, D. Hohenadel, P. T. Brinkkoetter, F. J. van der Woude, R. Waldherr, T. J. Rabelink, H. E. de, and J. A. Bruijn. Reduction of VEGF-A and CTGF expression in diabetic nephropathy is associated with podocyte loss. Kidney Int. 71:637-645 (2007).

137. A. Igarashi, H. Okochi, D. M. Bradham, and G. R. Grotendorst. Regulation of connective tissue growth factor gene expression in human skin fibroblasts and during wound repair. Mol. Biol. Cell. 4:637-645 (1993).

138. D. Iwanciw, M. Rehm, M. Porst, and M. Goppelt-Struebe. Induction of connective tissue growth factor by angiotensin II: integration of signaling pathways. Arterioscler Thromb Vasc Biol. 23:1782-1787 (2003).

139. S. Gauer, V. Segitz, and M. Goppelt-Struebe. Aldosterone induces CTGF in mesangial cells by activation of the glucocorticoid receptor. Nephrol. Dial. Transplant. 22:3154-3159 (2007).

140. D. F. Higgins, M. P. Biju, Y. Akai, A. Wutz, R. S. Johnson, and V. H. Haase. Hypoxic induction of Ctgf is directly mediated by Hif-1. Am. J. Physiol. Renal. Physiol. 287:F1223-F1232 (2004).

141. C. Ott, D. Iwanciw, A. Graness, K. Giehl, and M. GoppeltStruebe. Modulation of the expression of connective tissue growth factor by alterations of the cytoskeleton. J. Biol. Chem. 278:44305-44311 (2003).

142. S. Kubota, T. Hattori, T. Nakanishi, and M. Takigawa. Involvement of cis-acting repressive element(s) in the $3^{\prime}$ untranslated region of human connective tissue growth factor gene. FEBS Lett. 450:84-88 (1999).

143. T. Eguchi, S. Kubota, S. Kondo, T. Shimo, T. Hattori, T. Nakanishi, T. Kuboki, H. Yatani, and M. Takigawa. Regulatory mechanism of human connective tissue growth factor (CTGF/ Hcs24) gene expression in a human chondrocytic cell line, HCS2/8. J. Biochem. (Tokyo) 130:79-87 (2001).

144. I. E. Blom, A. J. van Dijk, R. A. de Weger, M. G. Tilanus, and R. Goldschmeding. Identification of human $\mathrm{ccn} 2$ (connective tissue growth factor) promoter polymorphisms. Mol. Pathol. 54:192-196 (2001).

145. J. R. Ortlepp, F. Schmitz, V. Mevissen, S. Weiss, J. Huster, R. Dronskowski, G. Langebartels, R. Autschbach, K. Zerres, C. Weber, P. Hanrath, and R. Hoffmann. The amount of calciumdeficient hexagonal hydroxyapatite in aortic valves is influenced by gender and associated with genetic polymorphisms in patients with severe calcific aortic stenosis. Eur. Heart J. 25:514-522 (2004).

146. A. J. McKnight, D. A. Savage, C. C. Patterson, H. R. Brady, and A. P. Maxwell. Resequencing of the characterised CTGF gene to identify novel or known variants, and analysis of their association with diabetic nephropathy. J. Hum. Genet. 51:383386 (2006).

147. C. Fonseca, G. E. Lindahl, M. Ponticos, P. Sestini, E. A Renzoni, A. M. Holmes, P. Spagnolo, P. Pantelidis, P. Leoni, N. McHugh, C. J. Stock, X. Shi-Wen, C. P. Denton, C. M. Black, K. I. Welsh, R. M. du Bois, and D. J. Abraham. A polymorphism in the CTGF promoter region associated with systemic sclerosis. N. Engl. J. Med. 357:1210-1220 (2007).

148. K. Hishikawa, B. S. Oemar, F. C. Tanner, T. Nakaki, T. F. Luscher, and T. Fujii. Connective tissue growth factor induces apoptosis in human breast cancer cell line MCF-7. J. Biol. Chem. 274:37461-37466 (1999).

149. R. Goldschmeding, J. Aten, Y. Ito, I. Blom, T. Rabelink, and J. J. Weening. Connective tissue growth factor: just another factor in renal fibrosis? Nephrol. Dial. Transplant. 15:296-299 (2000)

150. S. M. Twigg, and M. E. Cooper. The time has come to target connective tissue growth factor in diabetic complications. Diabetologia 47:965-968 (2004).

151. Y. Shi, Z. Tu, W. Wang, Q. Li, F. Ye, J. Wang, J. Qiu, L. Zhang, $\mathrm{H}$. Bu, and Y. Li. Homologous peptide of connective tissue growth factor ameliorates epithelial to mesenchymal transition of tubular epithelial cells. Cytokine 36:35-44 (2006).

152. L. Chen, B. C. Liu, X. L. Zhang, J. D. Zhang, H. Liu, and M. X. Li Influence of connective tissue growth factor antisense oligonucleotide on angiotensin II-induced epithelial mesenchymal transition in HK2 cells. Acta Pharmacol Sin. 27:1029-1036 (2006).

153. H. Yokoi, M. Mukoyama, T. Nagae, K. Mori, T. Suganami, K. Sawai, T. Yoshioka, M. Koshikawa, T. Nishida, M. Takigawa, A. Sugawara, and K. Nakao. Reduction in connective tissue growth factor by antisense treatment ameliorates renal tubulointerstitial fibrosis. J. Am. Soc. Nephrol. 15:1430-1440 (2004).

154. H. Okada, T. Kikuta, T. Kobayashi, T. Inoue, Y. Kanno, M. Takigawa, T. Sugaya, J. B. Kopp, and H. Suzuki. Connective tissue growth factor expressed in tubular epithelium plays a pivotal role in renal fibrogenesis. J. Am. Soc. Nephrol. 16:133-143 (2005).

155. H. Okada, T. Kikuta, T. Inoue, Y. Kanno, S. Ban, T. Sugaya, M. Takigawa, and H. Suzuki. Dexamethasone induces connective tissue growth factor expression in renal tubular epithelial cells in a mouse strain-specific manner. Am. J. Pathol. 168:737-747 (2006).

156. M. Guha, Z. G. Xu, D. Tung, L. Lanting, and R. Natarajan. Specific down-regulation of connective tissue growth factor attenuates progression of nephropathy in mouse models of type 1 and type 2 diabetes. FASEB J. 21:3355-3368 (2007). 